\title{
Alcohol fixation of induced sputum samples for applications in rural communities
}

\author{
Sandra C Dorman $\mathrm{PhD}^{1}$, Melanie A Bussoli BSc ${ }^{1}$, Stacey A Ritz $\mathrm{PhD}^{2}$
}

SC Dorman, MA Bussoli, SA Ritz. Alcohol fixation of induced sputum samples for applications in rural communities. Can Respir J 2010;17(3):115-121.

BACKGROUND: Sputum induction is a tool recommended for the assessment of airway inflammation and disease management. Currently, its use is limited because samples need to be processed within $3 \mathrm{~h}$ of induction (ie, while cells are viable); therefore, this procedure is unavailable to most clinicians.

OBJECTIVE: To develop a fixation method for induced sputum samples that allows for a delay in processing while maintaining sample integrity and not altering the standard processing method.

METHODS: Sputum samples were collected and split into three portions: a fresh sample processed using the routine method (within $3 \mathrm{~h}$, using dithiothreitol); fixation in alcohol followed by delayed processing using the routine method (within $48 \mathrm{~h}$ to $72 \mathrm{~h}$, using dithiothreitol); and fixation in formaldehyde followed by delayed processing using an alternative method (within $48 \mathrm{~h}$ to $72 \mathrm{~h}$, using proteolysis). For each method, cytospins were prepared and differential cell counts were performed.

RESULTS: Fixation in alcohol provides accurate measures of eosinophils and macrophages, but not neutrophils. Formaldehyde fixation provides accurate measures of neutrophils and macrophages, but not eosinophils.

DISCUSSION: Alcohol fixation is a superior method for eosinophil quantification. It requires alteration of standardized methods for sputum sample processing and should be recommended for monitoring eosinophilic airway disease in settings where immediate processing of a sputum sample is not possible.

Key Words: Airway; Eosinophilic airway inflammation; Fixation; Rural; Sputum cytology; Sputum induction

\section{La fixation par l'alcool de l'expectoration induite pour des applications dans les communautés rurales}

HISTORIQUE : L'induction des expectorations est recommandée pour évaluer l'inflammation des voies aériennes et prendre en charge la maladie. Son utilisation est toutefois limitée car il faut traiter les échantillons dans les trois heures suivant l'induction (c'est-à-dire pendant que les cellules sont viables). Par conséquent, la plupart des cliniciens ne disposent pas de cette intervention.

OBJECTIF : Mettre au point une méthode de fixation des échantillons d'expectoration induite pour en retarder le traitement tout en en conservant l'intégrité et en évitant de modifier la méthode de traitement standard.

MÉTHODOLOGIE : Les chercheurs ont colligé des échantillons d'expectoration et les ont divisés en trois parties : un échantillon frais traité au moyen de la méthode habituelle (dans les trois heures, au moyen du dithiothréitol), la fixation dans l'alcool suivie d'un traitement retardé selon la méthode habituelle (dans les 48 à 72 heures, au moyen du dithiothréitol) et la fixation dans du formaldéhyde suivie d'un traitement retardé au moyen d'une autre méthode (dans les 48 à 72 heures au moyen de la protéolyse). Pour chaque méthode, on a préparé les cytospines et effectué une formule leucocytaire différentielle.

RÉSULTATS : La fixation dans l'alcool fournit des mesures précises des éosinophiles et des macrophages, mais pas des neutrophiles. La fixation dans le formaldéhyde assure des mesures précises des neutrophiles et des macrophages, mais pas des éosinophiles.

EXPOSÉ : La fixation dans l'alcool est une méthode supérieure de quantification des éosinophiles. Elle exige de modifier les méthodes standardisées de traitement d'échantillons d'expectoration et devrait être recommandée pour évaluer les maladies à éosinophiles des voies aériennes dans les milieux où il n'est pas possible de procéder au traitement immédiat d'un échantillon d'expectoration.

as the need for trained personnel to be available to perform the processing (16). Currently, the only available method in these communities is the preparation of a sputum smear. This method is used primarily to detect the presence of eosinophilia and cancer cells; however, because it does not involve the selection of cell plugs and relies on spontaneous production of sputum, many subjects are unable to induce a sample and, thus, few cells are collected and examined, resulting in a fundamentally qualitative analysis that lacks sufficient reliability and consistency.

Several groups have tried to develop a method to preserve sputum samples to have them forwarded to larger centres for processing. Holz et al (17) and Popov et al (18) demonstrated that samples can be successfully frozen for up to 10 days before processing. However, shipping frozen samples is costly and the method may not be feasible for clinical use in remote and rural areas if liquid nitrogen is not available. Kelly et al (19) tested a more cost-efficient method of shipping samples - by fixation in formaldehyde before processing. This preparation method, although easy and inexpensive to ship, requires significant changes in the sample processing method and increases the rural and remote populations, is currently restricted by the need to process the sample on the day of collection (15) as well

\footnotetext{
${ }^{1}$ School of Human Kinetics, Laurentian University; ${ }^{2}$ Northern Ontario School of Medicine, Sudbury, Ontario

Correspondence and reprints: Dr Sandra C Dorman, School of Human Kinetics, Laurentian University, 935 Ramsey Lake Road, Sudbury,

Ontario P3E 2C6. Telephone 705-675-1151 ext 1015, fax 705-675-4845, e-mail sdorman@laurentian.ca
} 
cost of processing. Since the original method of sputum processing was developed by Popov et al (20) in 1994, many laboratories around the world have accepted, tested and implemented this technique. The fixation method proposed by Kelly et al (19) would require the retraining of technicians who currently perform sputum sample processing using standardized techniques, and the introduction of novel methods for cell dispersion.

The aim of the present study was to develop a method that allows for delayed processing and examination of sputum samples without significantly altering standard protocols while providing results that are consistent with those obtained from a fresh sample. Furthermore, the method should be economical and feasible for clinical use in rural and remote locations. We used alcohol to preserve induced sputum samples and compared the cell counts with those obtained from a portion of fresh sputum that was immediately processed using the routine method (using dithiothreitol [DTT] [7]) and a portion that was fixed in formaldehyde according to the procedures described by Kelly et al (19).

\section{METHODS}

\section{Subjects}

Sputum samples were collected from 18 subjects (10 men, eight women; mean age 26 years): eight had mild stable asthma and 10 were healthy, nonasthmatic individuals. All subjects had a baseline forced expiratory volume in $1 \mathrm{~s}$ of greater than $80 \%$ of predicted, were not taking any medications (except intermittent beta-2 agonist use) and were free from respiratory infection. Five subjects (two subjects with asthma [one man, one woman] and three healthy nonasthmatic patients [one man, two women]) were unable to produce an adequate amount of sputum and were subsequently excluded from the study. The study protocol was approved by the Laurentian University Ethics Board (Sudbury, Ontario) and all subjects provided written informed consent to participate in the study.

\section{Study design}

The present study was a prospective, cross-sectional study in which induced sputum samples from 13 subjects were randomly divided into three portions. One portion was processed fresh by the routine method, a second was fixed in alcohol and processed by the routine method, with the third portion fixed in formaldehyde and processed by the method described by Kelly et al (19). Total and differential cell counts were compared among the three methods. All samples were coded and sputum cell counts were performed blind to the processing method and subject details. The same technologist examined the total cell counts in all samples from the same subject (fresh, formaldehyde fixed and alcohol fixed) and one technologist performed the differential cell counts on all slides prepared.

\section{Procedures}

Sputum induction: Sputum was induced by hypertonic saline inhalation and processed according to Pin et al (3) and modified according to Pizzichini et al (7).

Sputum processing: Sputum was isolated from the expectorate as described by Pizzichini et al (7) within $3 \mathrm{~h}$ of collection and divided into three approximately equal portions and randomly assigned to be processed in the following ways: immediately using the routine method; after preservation with alcohol using the routine method; or after preservation with formaldehyde using the method of Kelly et al (19).

Routine method: Fresh sputum samples were processed within $3 \mathrm{~h}$ of collection using the method described by Pizzichini et al (7). Briefly, 0.1\% DTT (Sputolysin, Calbiochem, USA) was added at four times the volume of the selected sample, rocked for $15 \mathrm{~min}$ and neutralized with phosphate-buffered saline. The sample was then filtered, followed by cell quantification and slide production. Slides were stained with Diff Quik (Dade Behring Inc, USA) and a differential cell count was performed by counting 400 nonsquamous cells from duplicate slides.

Alcohol preservation: The sample was immersed in $30 \mathrm{~mL}$ of $50 \%$ (by volume) ethyl alcohol and stored at room temperature for $48 \mathrm{~h}$ to $72 \mathrm{~h}$, after which the sample was removed and swirled in a petri dish to allow excess alcohol to evaporate. The sample was then processed according to Pizzichini et al (7), identical to the routine method described above. Slides were stained with Diff Quik and a differential cell count was performed by counting 400 nonsquamous cells from duplicate slides.

Formaldehyde preservation: The sample was immersed in $2 \%$ paraformaldehyde and stored at room temperature for $48 \mathrm{~h}$ to $72 \mathrm{~h}$, after which the fixative was removed by washing with phosphate-buffered saline three times and then processed according to Kelly et al (19). Briefly, a solution ( $3 \mathrm{~mL}$ [weight by volume], working concentration approximately $2 \%$ ) of $2.5 \%$ trypsin (Sigma-Aldrich, Canada; 0.05 M tris-buffered saline with $0.1 \%$ calcium chloride) was added to the sample. After vortexing, the solution was incubated at $37^{\circ} \mathrm{C}$ for $6 \mathrm{~h}$ to $17 \mathrm{~h}$. The dispersed sputum was then briefly vortexed and filtered. The total cell count was determined and cytospins were prepared. Slides were stained with Diff Quik and a differential cell count was performed by counting 400 nonsquamous cells from duplicate slides.

\section{Statistical analysis}

Sputum cell counts were expressed as median with interquartile range. Comparisons between cell counts were made using Wilcoxon's signed-rank test for paired data. Intraclass correlation was calculated to determine association and agreement between the alternative fixation methods and the routine method. In addition, to quantify the magnitude of the difference between fixation methods and the routine method, a Bland-Altman analysis was performed (21); results were expressed as the mean difference with 95\% CIs. A two-tailed $\mathrm{P}<0.05$ was considered to be statistically significant.

\section{RESULTS}

\section{Alcohol fixation}

The total cell counts obtained by the routine and alcohol-fixed methods were significantly correlated, with a small but insignificant decrease observed between samples (routine: $0.8 \times 10^{6}$ cells/g; alcohol: $0.4 \times 10^{6} \mathrm{cell} / \mathrm{g}$ ) (Figure $1 \mathrm{~A}$ ), likely attributed to the near-significant decrease in absolute numbers of neutrophils $(\mathrm{P}=0.07)$. Both the per cent and absolute cell counts of eosinophils correlated significantly (Figure 2A) between methods and had a near-zero measure bias. The absolute cell counts of macrophages (Figure 3A) correlated significantly; however, a significantly higher percentage of macrophages were observed 

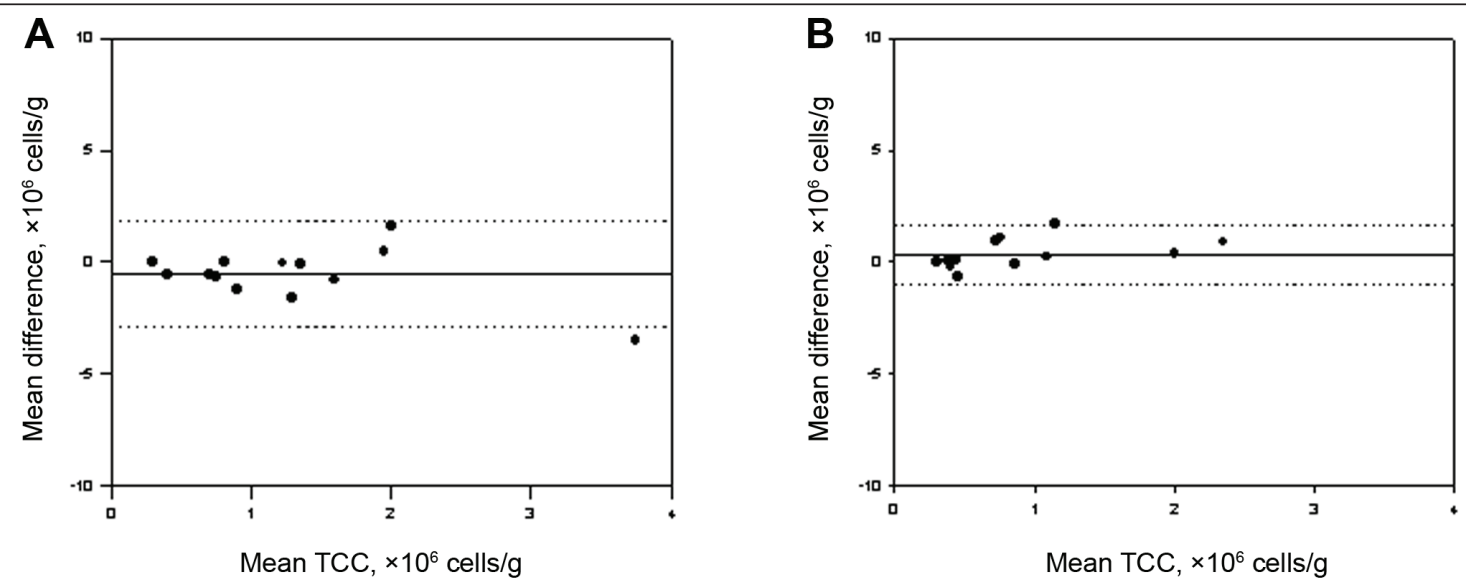

Figure 1) Bland-Altman plots of mean differences versus mean values of total cell count (TCC) show the agreement between samples processed by the two different methods. A Total sputum cell counts from aliquots from the same sample processed by the routine and formaldehyde preservation methods. B Total sputum cell counts from aliquots from the same sample processed by the routine and alcohol preservation methods. The solid line represents the mean difference (see also Tables 1 and 2), the dotted lines indicate \pm 1.96 SDs from the mean (ie, 95\% CIs)
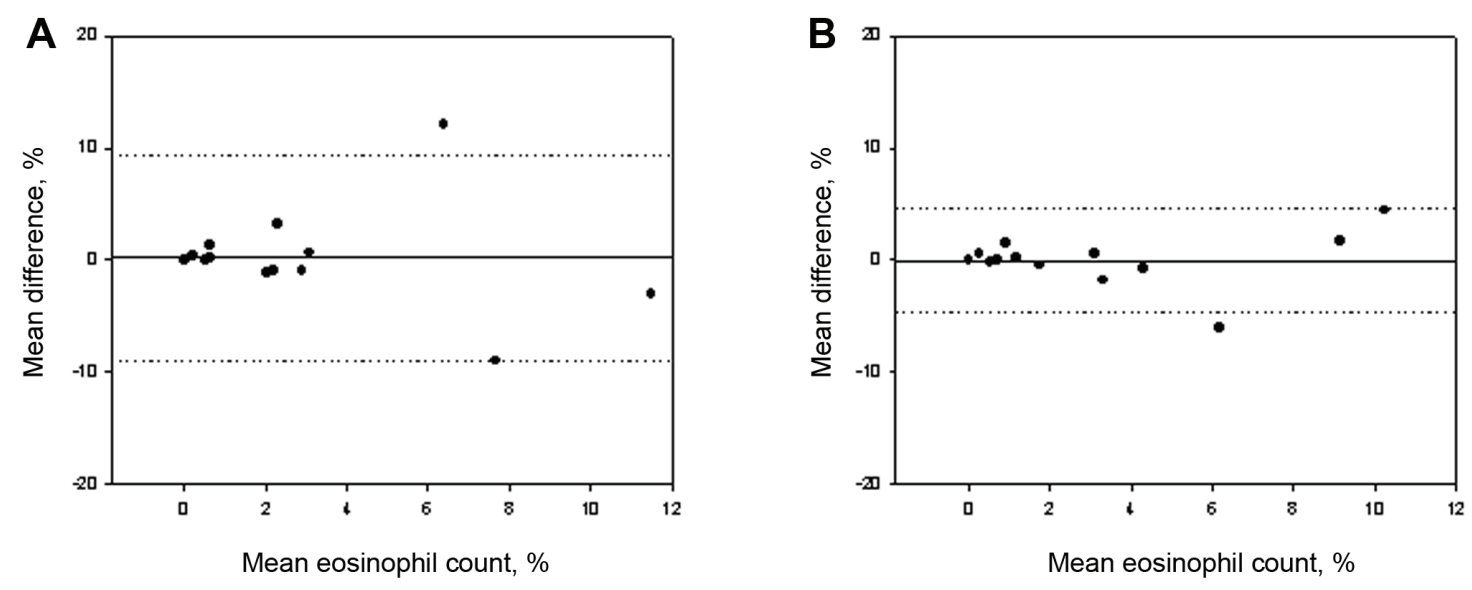

Figure 2) Bland-Altman plots of mean differences versus mean values of per cent eosinophils show the agreement between samples processed by two different methods. A Per cent eosinophil cell counts from aliquots from the same sample processed by the routine and formaldehyde preservation method. B Per cent eosinophil cell counts from aliquots from the same sample processed by the routine and alcohol preservation methods. The solid line represents the mean difference (see also Tables 1 and 2), the dotted lines indicate \pm 1.96 SDs from the mean (ie, 95\% CIs)
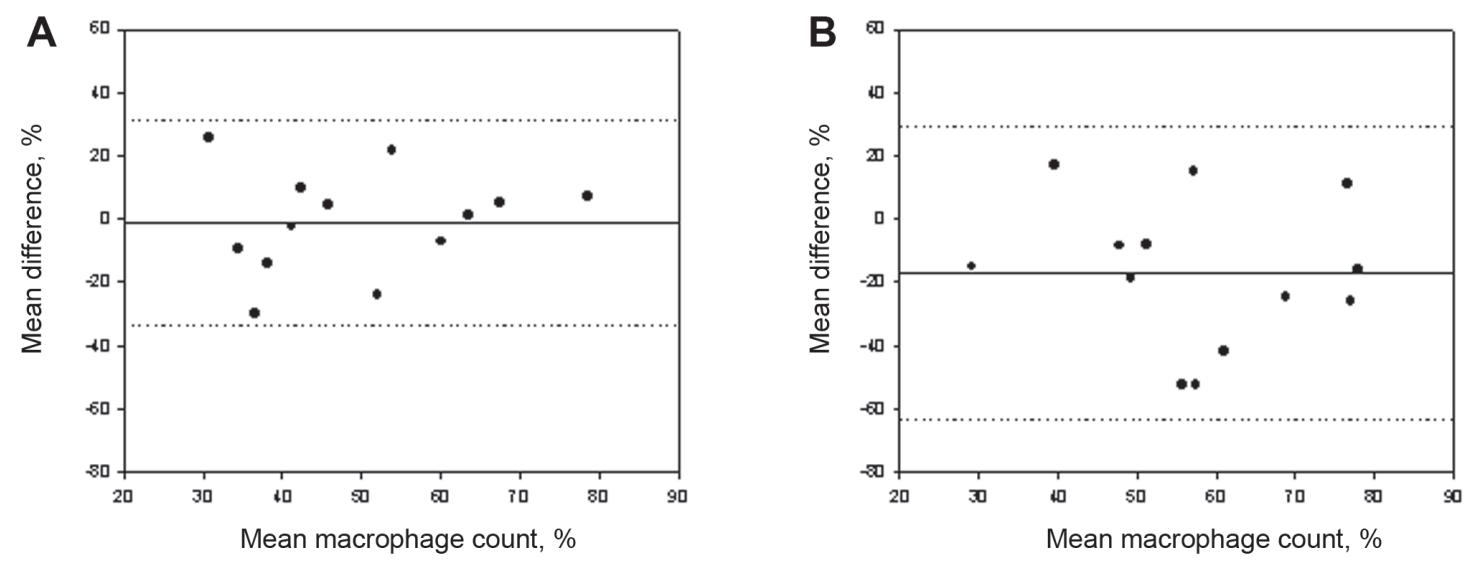

Figure 3) Bland-Altman plots of mean differences versus mean per cent macrophages show the agreement between samples processed by two different methods. A Per cent macrophage cell counts from aliquots from the same sample processed by the routine and formaldehyde preservation method. B Per cent macrophage cell counts from aliquots from the same sample processed by the routine and alcohol preservation methods. The solid line represents the mean difference (see also Tables 1 and 2), the dotted lines indicate \pm 1.96 SDs from the mean (ie, 95\% CIs) 

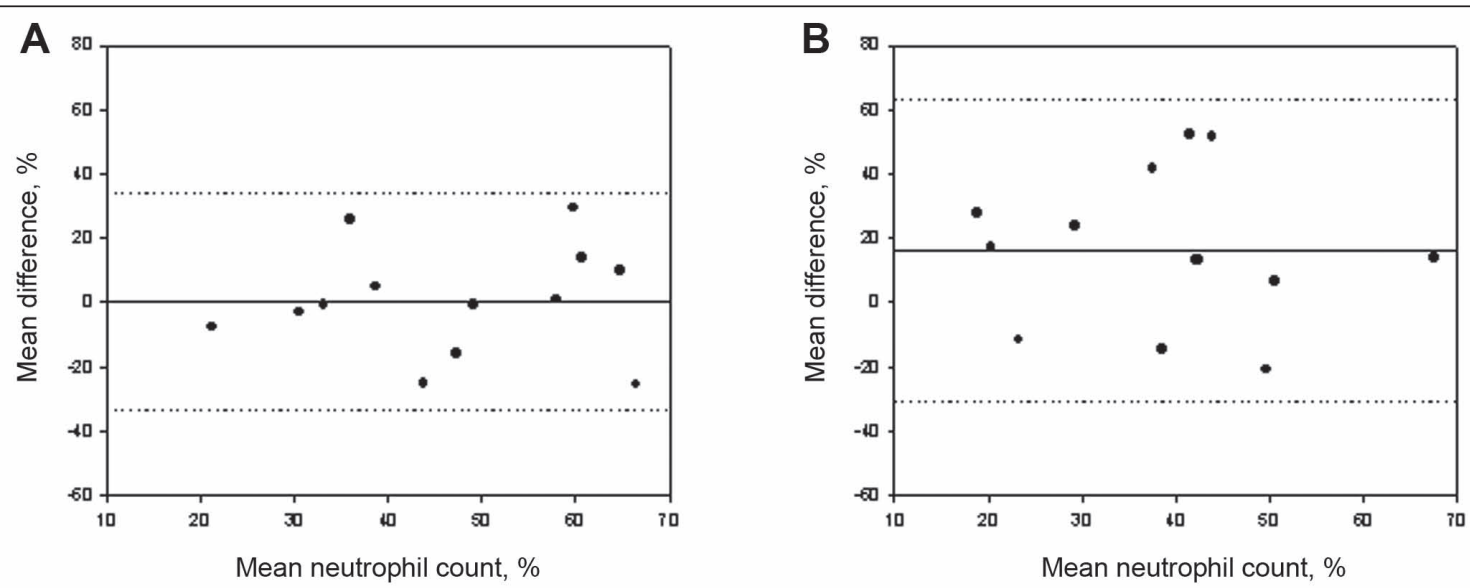

Figure 4) Bland-Altman plots of mean differences versus mean values of per cent neutrophil cell counts show the agreement between samples processed by the two different methods. A Per cent neutrophil cell counts from aliquots from the same sample processed by the routine and formaldehyde preservation methods. B Per cent neutrophil cell counts from aliquots from the same sample processed by the routine and alcohol preservation methods. The solid line represents the mean difference (see also Tables 1 and 2), the dotted lines indicate \pm 1.96 SDs from the mean (ie, 95\% CIs)

TABLE 1

Comparison of cellular indexes in sputum processed fresh and preserved in alcohol

\begin{tabular}{|c|c|c|c|c|c|}
\hline & \multicolumn{2}{|c|}{ Preservation method } & \multirow{2}{*}{$\begin{array}{c}\text { P } \\
\text { (Wilcoxon) }\end{array}$} & \multirow{2}{*}{$\begin{array}{c}\text { Intraclass correlation } \\
\text { coefficient }\end{array}$} & \multirow{2}{*}{$\begin{array}{c}\text { Bias } \\
\text { (mean difference }[95 \% \mathrm{Cl}] \text { ) }\end{array}$} \\
\hline & Routine (fresh) & Alcohol & & & \\
\hline Total cell count, $\times 10^{6}$ cells $/ g$ & $0.8(0.80)$ & $0.4(0.63)$ & 0.13 & $0.60^{\star}$ & $-0.3(-0.7$ to 0.1$)$ \\
\hline Eosinophils, \% & $1.7(2.87)$ & $2.0(5.01)$ & 0.85 & $0.79^{*}$ & $0.0(-1.4$ to 1.4$)$ \\
\hline Eosinophils, $\times 10^{4}$ & $1.2(3.05)$ & $0.5(3.99)$ & 0.91 & $0.58^{\star}$ & $0.18(-1.2$ to 1.5$)$ \\
\hline Neutrophils, \% & $48.8(28.33)$ & $29.0(29.95)$ & $0.008^{*}$ & 0.15 & $-16.5(-30$ to -2$)$ \\
\hline Neutrophils, $\times 10^{4}$ & $27.0(72.14)$ & $10.0(38.45)$ & 0.07 & -0.07 & $-0.5(-1.0$ to 1.0$)$ \\
\hline Macrophages, \% & $47.3(26.51)$ & $71.0(31.01)$ & $0.03^{\star}$ & 0.24 & $16.9(-3.0$ to 31.0$)$ \\
\hline Macrophages, $\times 10^{4}$ & $26.0(71.05)$ & $27.6(13.82)$ & 0.3 & $0.83^{\star}$ & $-10.3(-30.0$ to 9.0$)$ \\
\hline
\end{tabular}

Data presented as median (interquartile range) unless indicated otherwise. * Statistically significant $(P<0.05)$

TABLE 2

Comparison of cellular indexes in sputum processed fresh and preserved in formaldehyde

\begin{tabular}{|c|c|c|c|c|c|}
\hline & \multicolumn{2}{|c|}{ Preservation method } & \multirow{2}{*}{$\begin{array}{c}\text { P } \\
\text { (Wilcoxon) }\end{array}$} & \multirow{2}{*}{$\begin{array}{c}\text { Intraclass correlation } \\
\text { coefficient }\end{array}$} & \multirow{2}{*}{$\begin{array}{c}\text { Bias } \\
\text { (mean difference }[95 \% \mathrm{Cl}] \text { ) }\end{array}$} \\
\hline & Routine (fresh) & Formaldehyde & & & \\
\hline Total cell count, $\times 10^{6}$ cells $/ g$ & $0.8(0.80)$ & $1.25(0.70)$ & 0.08 & 0.4 & $-0.54(-1.84$ to 1.3$)$ \\
\hline Eosinophils, \% & $1.7(2.87)$ & $0.7(2.66)$ & 0.97 & 0.38 & $-0.02(-3.0$ to 2.6$)$ \\
\hline Eosinophils, $\times 10^{4}$ & $1.2(3.05)$ & $0.7(8.02)$ & 0.42 & 0.23 & $3.6(1.2$ to 8.5$)$ \\
\hline Neutrophils, \% & $48.8(28.33)$ & $49.6(23.49)$ & 0.9 & $0.49 *$ & $-0.5(-10.0$ to 10.0$)$ \\
\hline Neutrophils, $\times 10^{4}$ & $27.0(72.14)$ & $46.0(37.13)$ & 0.2 & 0.09 & $-0.2(0.8$ to 0.4$)$ \\
\hline Macrophages, \% & $47.3(26.51)$ & $45.1(22.1)$ & 0.9 & $0.52^{\star}$ & $1.0(-9.0$ to 11.0$)$ \\
\hline Macrophages, $\times 10^{4}$ & $26.0(71.05)$ & $63.6(53.17)$ & 0.4 & 0.41 & 14.6 (-18 to 48$)$ \\
\hline
\end{tabular}

Data presented as median (interquartile range) unless indicated otherwise. *Statistically significant $(P<0.05)$

in the alcohol-fixed sample. This discrepancy is explained by the neutrophil counts. As the absolute number of neutrophils decrease, so will the percentage of neutrophils. A real decrease in the percentage of one cell type will cause an apparent increase in another. The percentage of neutrophils was significantly decreased using the alcohol preservation method (Figure 4A, Table 1).

\section{Formaldehyde fixation}

The total cell counts obtained by the routine and formaldehydefixation methods did not correlate significantly. A trend toward an increase in total cell counts was detected when cells were fixed in formaldehyde compared with cell counts obtained by the routine method $(\mathrm{P}=0.08)$ (Figure $1 \mathrm{~B})$. This is reflected by the increase in absolute cell counts of eosinophils, neutrophils and macrophages. There was no correlation between the absolute or per cent eosinophil cell counts determined by the formaldehyde fixation and routine methods (Figure 2B). The percentage of neutrophils and macrophages determined by the formaldehyde fixation method correlated significantly with the routine method $(r=0.49 ; r=0.52$, respectively). Similarly, the magnitude of the mean difference was near zero for the percentage measurements. There was no correlation between methods for the absolute cell counts of neutrophils and macrophages (Figure 3B, Figure 4B) (Table 2). 


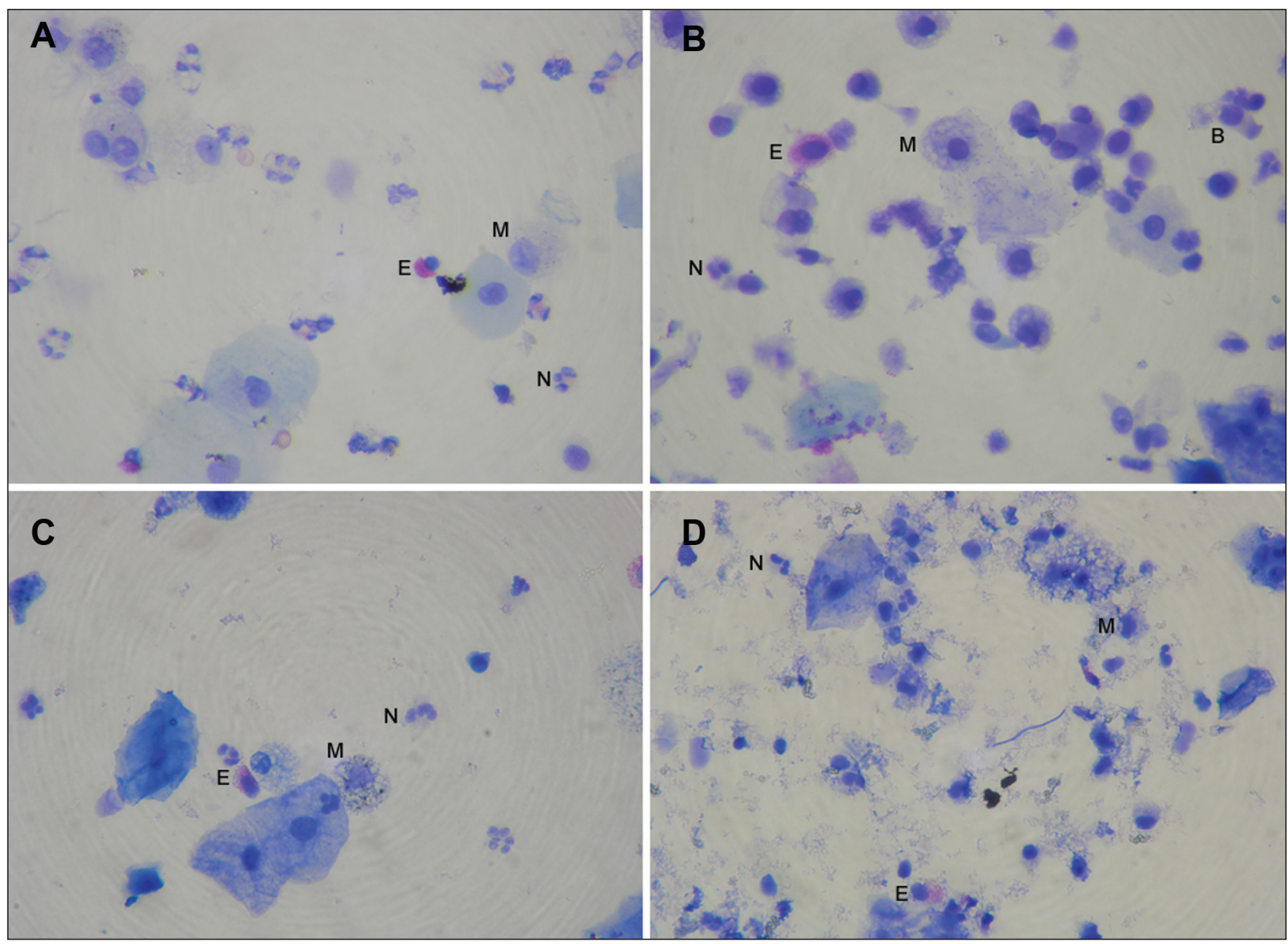

Figure 5) Comparison of cell morphology (Diff Quik stain, Dade Behring, USA) between fresh sample prepared using the routine method (A), sample preserved in alcohol and prepared by the routine method (B), sample preserved in formaldehyde and prepared using the method of Kelly et al (19) (C), and sample preserved in formaldehyde (D), with moderate debris accumulation. B Bronchial epithelial cell; E Eosinophil; M Macrophage; N Neutrophil

\section{Cell viability}

The median $( \pm$ SD) cell viability (measured according to trypan blue exclusion) using the routine method was $71.5 \pm 13.8 \%$. Cell viability could not be measured with the alcohol or formaldehyde preservation methods.

\section{Morphology}

In general, the routine method preserved slides with a clean background and free from debris. Formaldehyde fixation using the novel processing method resulted in varying amounts of debris accumulation on the slides. Cell classification became more difficult as the quantity of debris increased. This debris was not apparent using the alcohol-fixation method, which appeared similar to the routine method; however, an increase in neutrophilic apoptosis was noted with this method. Furthermore, to obtain the best results with either preservation method, cells were required to be preserved as soon as possible after collection (Figure 5).

\section{DISCUSSION}

The present study compared total and differential cell counts between sputum samples processed within $3 \mathrm{~h}$ of collection by the routine method (using DTT), with those processed after a delay of $48 \mathrm{~h}$ to $72 \mathrm{~h}$ using two alternative preservation methods. Alcohol fixation is a novel preservation method used to delay processing of biological samples. Sputum samples fixed in alcohol were processed using DTT (routine method) in the present study. Formaldehyde-fixed samples were processed by a novel method proposed by Kelly et al (19). The present study is the first to describe and investigate the functionality of alcohol fixation of sputum samples. In agreement with the findings of Kelly et al (19), we found that formaldehyde fixation decreased total cell losses, likely by protecting cells from the deleterious effects of DTT on cell viability $(22,23)$. However, in contrast to the findings of Kelly et al (19), we did not find strong correlations between the differential cell counts obtained with either alternative method. Mean absolute cell counts were not significantly different from counts obtained using the routine method, nor was there a correlation between individual data points. The per cent cell counts correlated significantly for macrophages and neutrophils - but not eosinophils - and showed small differences in the magnitude of the mean difference between measurements. These differences were likely attributable to actual increases in cells measured and the 
obstruction of counts due to debris. Kelly et al (19) reported the accumulation of debris in their study and speculated that the extent of debris accumulation may reflect the degree of airway inflammation (personal communication). We note that high eosinophil counts tend to occur during periods of increased airway inflammation. Therefore, potentially, these cell counts were significantly different in the formaldehydefixed population due to an increase in debris, which obscured cell morphology. This would suggest a legitimate drawback to formaldehyde fixation because many clinical uses for sputum assessment involve the quantification of eosinophils to gauge airway inflammation.

In contrast, alcohol fixation provided a strong correlation with both per cent and absolute eosinophil counts, with nearzero differences between methods. Similarly, absolute macrophage counts correlated significantly with counts obtained using the routine method. Per cent macrophages were significantly higher in alcohol-fixed samples; however, this was very likely due to the reduction in neutrophil numbers, which artificially inflated the proportion of other cell types. There was a noticeable increase in neutrophilic cell death on the alcoholfixed slides. Notably, there was no accumulation of cellular debris using this method.

These observations support the contention that alcohol or formaldehyde fixation are not as effective as processing fresh samples for sputum quantification. However, for scenarios in which processing samples within $3 \mathrm{~h}$ of collection is not an option, we believe that both methods offer potential utility. In the case of eosinophilic airway diseases, our findings indicate that the alcohol fixation preservation method is superior to formaldehyde fixation.

Sputum eosinophilia is positively correlated with the degree of clinical improvement in response to inhaled corticosteroids and is more closely related to clinical response (2). In addition, sputum cell measurements using the routine method are well validated and normal ranges from a relatively large adult population have been published (24). Consistent with these developments, sputum induction is currently being recommended for use in the management of airway diseases $(2,14,25)$. The major categories of airway disease (asthma, chronic obstructive pulmonary disease and chronic cough) are associated with airway inflammation and it is of particular importance to determine whether sputum eosinophil count is elevated because each condition can be classified as either eosinophilic or noneosinophilic in nature (26-28). The presence of $3 \%$ or higher eosinophilia predicts the responsiveness of a patient to inhaled corticosteroids - that is, patients with baseline sputum eosinophil counts lower than 3\% show little improvement in symptoms, and patients with $3 \%$ or greater eosinophilia show favourable responses to corticosteroids $(2,26)$. In addition, monitoring eosinophil levels during therapy can predict recurrence of disease. For example, in asthma studies in which corticosteroid use was tapered, sputum eosinophilia developed well before the onset of an exacerbation, suggesting that targeted therapy aimed at normalizing sputum eosinophil counts could lead to a reduction in symptoms $(8,11)$. To implement the recommendation of sputum monitoring for airway disease management $(14,25)$, a fixation method is required for many communities where the capacity to process fresh sputum samples is not available locally. We suggest that alcohol fixation be the preferred method for this type of monitoring because it provides more accurate measures of eosinophilia than fresh processing using the routine method (from which all normal ranges have been developed), and samples can be shipped to centres and be processed by technicians already familiar with the routine method. It is also worth mentioning that the disposal of alcohol is safer and more environmentally friendly than disposing formaldehyde, which, as a toxic substance, requires special disposal methods.

For other airway diseases, such as lung carcinoma, tuberculosis or neutrophilic airways disease, formaldehyde fixation would be the preferred method. Importantly, there would likely be little airway inflammation in these subjects, which would minimize debris accumulation.

\section{CONCLUSION}

We have described a novel, convenient method for preservation and qualification of sputum samples that allow for the collection of sputum in a primary care setting and its subsequent transportation to a specialized centre for processing. This would encourage more widespread use of sputum as a clinical tool, as recommended for airway management. In addition, we have provided a comparison of this method with an alternative, previously described method.

FUNDING: The authors gratefully acknowledge financial support from the Laurentian University Research Fund and the Occupational Health Clinics for Ontario Workers.

ACKNOWLEDGEMENTS: The authors thank the Occupational Health Clinics for Ontario Workers for their support in the completion of this project. The authors also thank the volunteer subjects who participated in this study, as well as Jesse Wright for his technical assistance.

\section{REFERENCES}

1. Wang G, Lee Y, R Perng. A novel method of sputum processing for cytologic diagnosis of lung cancer. Analyt Quant Cyt Hist 2004;26:121-6.

2. Brightling CE. Clinical applications of induced sputum. Chest 2006;129:1344-8.

3. Pin I, Gibson PG, Kolendowicz R, et al. Use of induced sputum cell counts to investigate airway inflammation in asthma. Thorax 1992;47:25-9.

4. Pizzichini E, Pizzichini MMM, Efthimiadis A, Hargreave FE, Dolovich J. Measurement of inflammatory indices in induced sputum: Effects of selection of sputum to minimize salivary contamination. Eur Respir J 1996;9:1174-80.

5. Pizzichini MMM, Pizzichini E, Efthimiadis A, et al. Asthma and natural colds. Inflammatory indices in induced sputum: A feasibility study. Am J Respir Crit Care Med 1998;158:1178-84.

6. Sagel SD, Chmiel JF, Konstan MW. Sputum biomarkers of inflammation in cystic fibrosis lung disease. Proc Am Thor Soc 2007;4:406-17.

7. Pizzichini E, Pizzichini MMM, Efthimiadis A, et al. Indices of airway inflammation in induced sputum: Reproducibility and validity of cell and fluid-phase measurements. Am J Respir Crit Care Med 1996;154:308-17.

8. Green RH, Brightling CE, McKenna S, et al. Asthma exacerbations and sputum eosinophil counts: A randomised controlled trial. Lancet 2002;360:1715-21.

9. Siva R, Green RH, Brightling CE, et al. Eosinophilic airway inflammation and exacerbations of COPD: A randomised controlled trial. Eur Respir J 2007;29:906-13.

10. Little SA, Chalmers GW, Macleod KJ, McSharry C, Thomson NC. Non-invasive markers of airway inflammation as predictors of oral steroid responsiveness in asthma. Thorax 2000;55:232-4. 
11. Jayaram L, Pizzichini MM, Cook RJ, et al. Determining asthma treatment by monitoring sputum cell counts: Effect on exacerbations. Eur Respir J 2006;27:483-94.

12. Pizzichini E, Pizzichini MMM, Gibson P, et al. Sputum eosinophilia predicts benefit from prednisone in smokers with chronic obstructive bronchitis. Am J Respir Crit Care Med 1998;158(5 Pt 1):1511-7.

13. Conde, MB, Soares, SL, Mello, et al. Comparison of sputum induction with fiberoptic bronchoscopy in the diagnosis of tuberculosis. Am J Respir Crit Care Med 2000;162:2238-40.

14. Bateman ED, Hurd SS, Barnes PJ, et al. Global strategy for asthma management and prevention: GINA executive summary. Eur Respir J 2008;31:143-78.

15. Effthimiadis A, Jayaram L, Weston S, Carruthers S, FE Hargreave. Induced sputum: Time from expectoration to processing. Eur Respir J 2002;19:706-8.

16. Bettschart RW, El-Kushman H, Spanevello A, Myers JD, Shakur H, Ind PW. Effect of storage on differential cell counts in induced sputum from COPD patients, smokers and normal subjects. Am J Respir Crit Care Med 1998;157:A812.

17. Holz O, Mücke M, Zarza P, Loppow D, Jörres RA, Magnussen H. Freezing of homogenized sputum samples for intermittent storage. Clin Exp Allergy 2001;31:1328-31.

18. Popov TA, Petlichkovski A, Mustakov TB, DuBuske LM, Popova DN. Assessment of a protocol for sputum freezing and subsequent examination. J Allergy Clin Immunol 2004;113:S193.

19. Kelly MM, Hargreave FE, Cox GE. A method to preserve sputum for delayed examination. Eur Respir J 2003;22:996-1000.

20. Popov TA, Gottschalk R, Kilendowicz R, Dolovich J, Powers J, Hargreave FE. The evaluation of a cell dispersion method of sputum examination. Clin Exp Allergy 1994;24:778-83.
21. Bland JM, Altman DG. Statistical methods for assessing agreement between two methods of clinical measurement. Lancet 1986;1:307-10.

22. Efthimiadis A, Pizzichini MM, Pizzichini E, Dolovich J, Hargreave FE. Induced sputuem cell and fluid phase indices of inflammation: Comparison of treatment with DTT versus PBS. Eur Respir J 1997;10:1336-40.

23. Pignatti P, Delmastro M, Perfetti L. Is dithiothreitol affecting cells and soluble mediators during sputum processing? A modified methodology to process sputum. J Allergy Clin Immunol 2002;110:667-8

24. Belda J, Leigh R, Parameswaran K, O'Byrne PM, Sears MR, Hargreave FE. Induced sputum cell counts in healthy adults. Am J Respir Crit Care Med 2000;151(2 Pt 1):475-8.

25. Pavord I, Sterk PJ, Hargreave FE, et al. Clinical applications of assessment of airway inflammation using induced sputum. Eur Respir J 2002;20:40s-43s.

26. Green RH, Brightling CE, Woltmann G, Parker D, Wardlaw AJ, Pavord ID. Analysis of induced sputum in adults with asthma: Identification of subgroup with isolated sputum neutrophilia and poor response to inhaled corticosteroids. Thorax 2002;57:875-9.

27. Brightling CE, Ward R, Goh KL, Wardlaw AJ, Pavord ID. Eosinophilic bronchitis is an important cause of chronic cough. Am J Respir Crit Care Med 1999;160:406-10.

28. Brightling CE, Monteiro W, Ward R. Sputum eosinophilia and short-term response to prednisolone in chronic obstructive pulmonary disease: A randomized controlled trial. Lancet 2000;356:1480-5. 


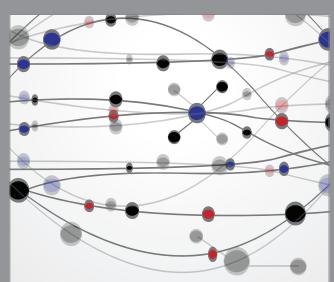

The Scientific World Journal
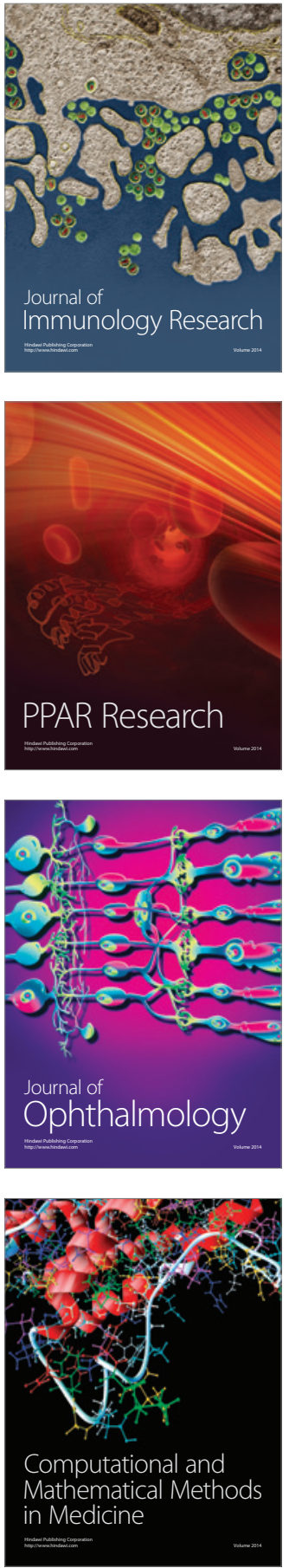

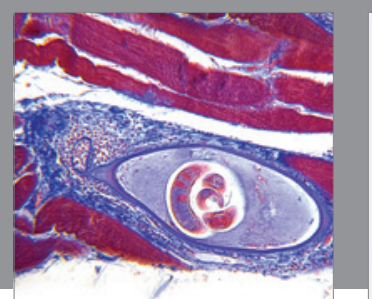

Gastroenterology Research and Practice

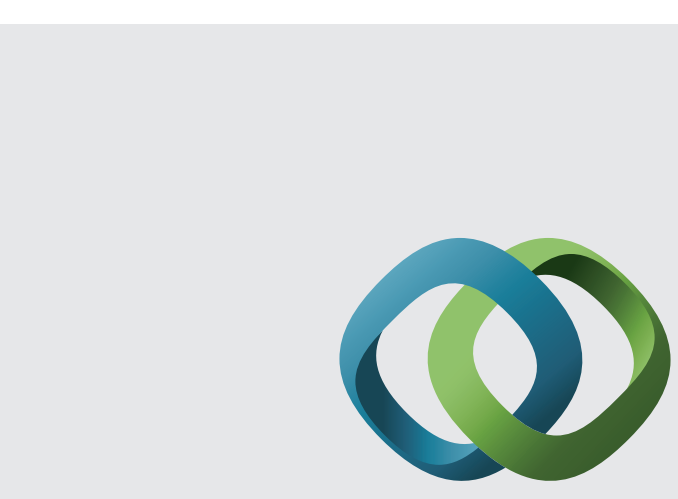

\section{Hindawi}

Submit your manuscripts at

http://www.hindawi.com
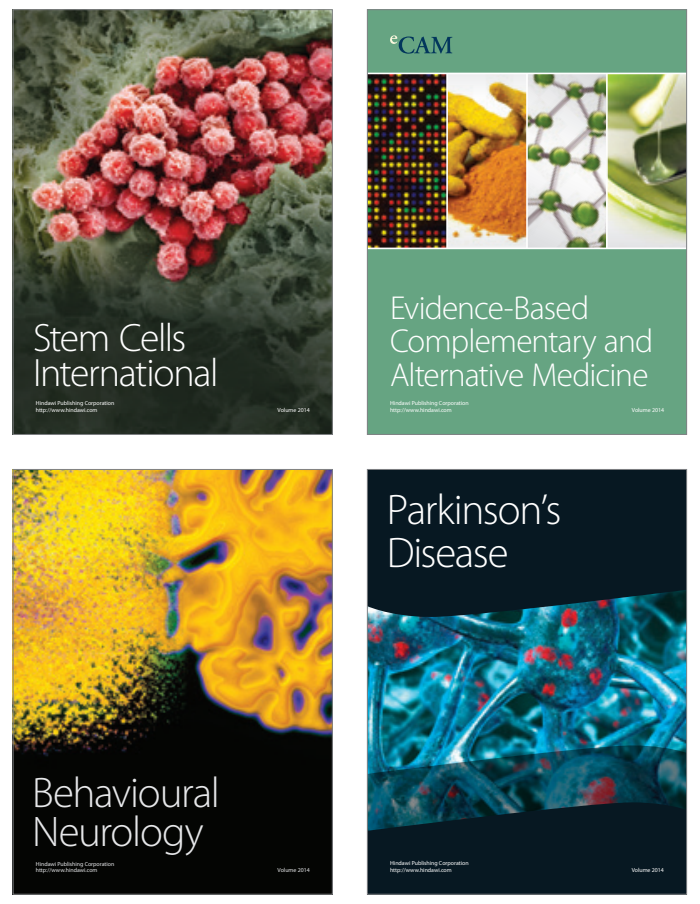
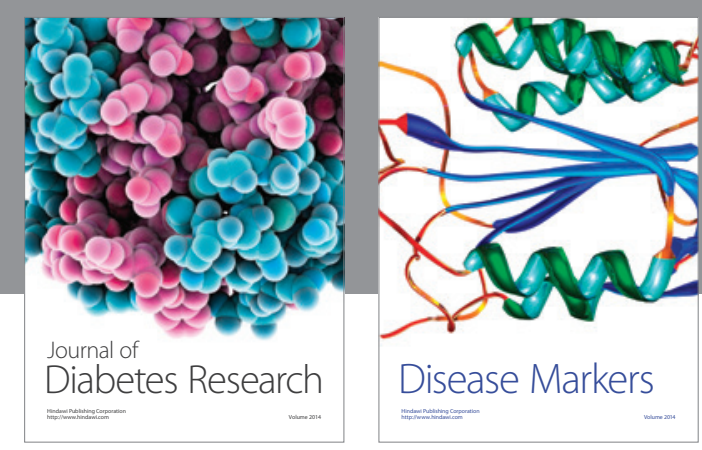

Disease Markers
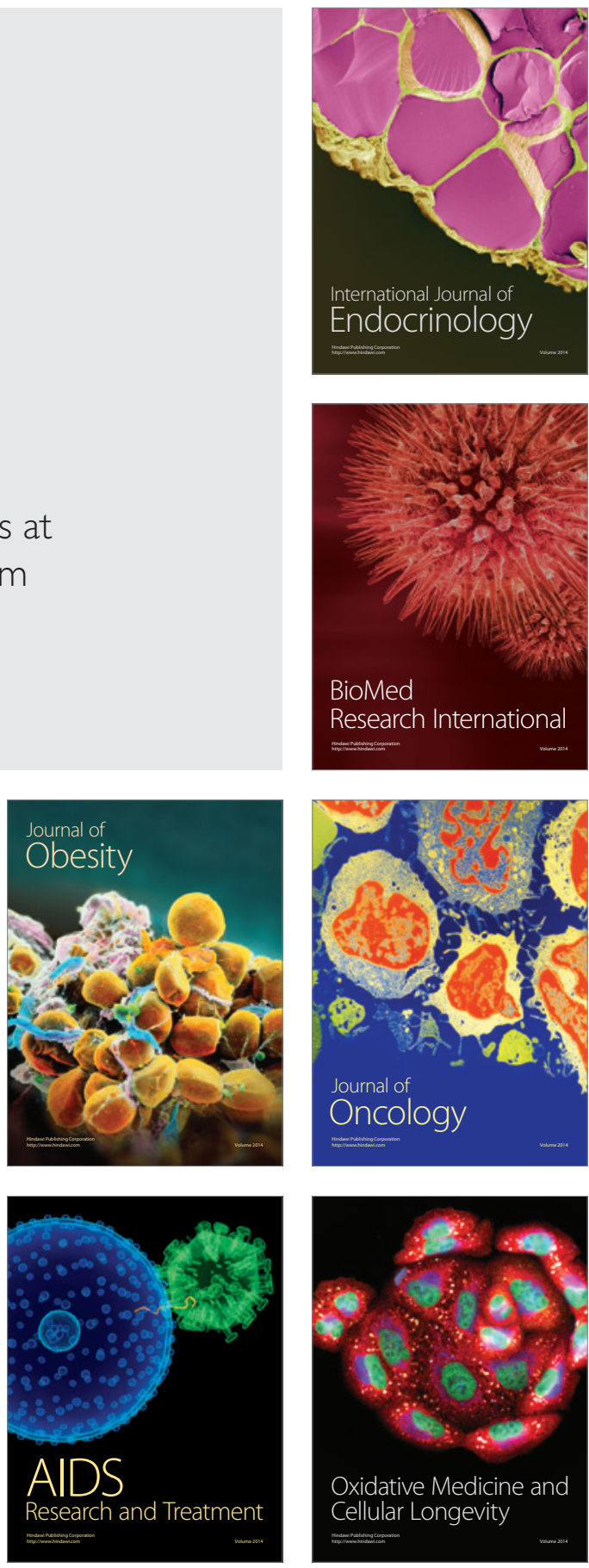